\section{RAHANPESIJÄN TIETOISUUUS VAROJEN LAITTOMASTA ALKUPERÄSTÄ TAHALLISUUSVAATIMUKSENA}

\section{MONEY LAUNDERER'S AWARENESS OF THE ILLEGAL ORIGIN OF PROPERTY AS A REQUIREMENT OF INTENT}

\section{Jenna Piippo'}

Helsinki Law Review, 1/2019, pp. 10-33

(c) 2019 Pykälä ry, Mannerheimintie 3 B, 5th floor, 00100 Helsinki, Finland, and the author.

\section{VERTAISARVIOITU
KOLLEGIALT GRANSKAD
PEER-REVIEWED}

Avainsanat:

rikosoikeus, tahallisuusvaatimus, olosuhdetahallisuus, rahanpesu, selonottovelvollisuus

Keywords:

criminal law, requirement of intent, circumstantial intent, money laundering, duty to investigate

\section{ABSTRACT}

This article discusses a money launderer's awareness of the illegal origin of property as a requirement of intent. The aim of the research is to find out what is required for fulfilling the requirement of intent. A money launderer's awareness of the illegal origin of property has been assessed in this article from the perspectives of theory and earlier legal practice.

The object of intent in money laundering is the property's illegal origin, to which the intent of the perpetrator must extend at the time of the act. The requirement of intent is fulfilled when the perpetrator perceives the illegal origin of the property to be a more likely alternative than its noncriminal origin. However, in some situations intent can also be based on negligence of the duty to investigate, even if the perpetrator had not perceived the property to be criminally obtained with a more than $50 \%$ certainty. The duty to investigate leads to a punishment for an intentional act especially in situations where the perpetrator, in order to avoid criminal liability, has not attempted to ascertain the origin of the property to a sufficient degree.

In practice, the fulfillment of the requirement of intent is based on the circumstances of the act, which means that the factors to be considered depend on each case.

1 Jenna Piippo is a third-year student at the Faculty of Law of the University of Lapland. This article is based on her Bachelor's Thesis.

\section{JOHDANTO}

\section{I.I Kirjoituksen lähtökohdat}

Tämä kirjoitus käsittelee rahanpesijän tietoisuutta varojen laittomasta alkuperästä tahallisuusvaatimuksena. Tahallisuus on yksi keskeisimmistä ja moniulotteisimmista rangaistusvastuuta määrittävistä rikosoikeudellisista käsitteistä. ${ }^{2}$ Se kuuluu rikosoikeuden yleisiin oppeihin, ja sillä on teoreettisen ulottuvuutensa lisäksi tärkeä sija käytännön lainsoveltamistoiminnassa. Tietämisellä voidaan tarkoittaa tahallisuutta yleensä. ${ }^{3}$

Tutkimus keskittyy rikoslain (39/1889) 32 luvun 6 §:n rahanpesusäännökseen, jonka täyttyminen edellyttää tekijältä tahallisuutta. Tutkimuskysymys on: "Mitkä ovat rahanpesijän tietoisuutta varojen laittomasta alkuperästä koskevan tahallisuusvaatimuksen täyttymisen edellytykset?". Tutkimuksellisena tarkoituksena on siis selvittää, mitä kyseisen tahallisuusvaatimuksen täyttyminen edellyttää. Arvioin kirjoituksessa lainopillisesta näkökulmasta rahanpesijän tietoisuutta varojen laittomasta alkuperästä yhtäältä teoreettisessa viitekehyksessä ja toisaalta miten sitä on tulkittu oikeuskäytännössä. Tahallisuutta ja sen täyttymistä rahanpesussa arvioidaan kansallisista lähtökohdista ${ }^{\mathbf{4}}$, ja kirjoituksen rajallisen pituuden vuoksi rahanpesijän tietoisuutta varojen laittomasta alkuperästä onkin tarkasteltu vain kotimaisen tahallisuuskeskustelun näkökulmasta.

Kirjoitus jakaantuu kolmeen päälukuun, joista kahdessa ensimmäisessä pääluvussa tutkin rahanpesijän tietoisuusvaatimusta teoreettisesta näkökulmasta. Näissä luvuissa käsittelen rahanpesijän tietoisuutta varojen laittomasta alkuperästä yleisesti tahallisuuden elementtinä sekä olosuhdetahallisuuden alarajasta käydyn keskustelun kautta. Käsittelen myös rikoslain 4 luvun $1 \S: n$ tunnusmerkistöerehdystä sekä selonottovelvollisuuttaja sen laiminlyönnin merkitystä rahanpesussa Viimeisessä eli kolmannessa päl̈luvussa tarkastelen rahanpesun tahallisuusarviointiin vaikuttavia seikkoja etenkin aikaisempien tuomioistuinratkaisujen valossa.

\section{I.2 Rahanpesu ja tahallisuus yleisesti}

Rahanpesu kriminalisoitiin rikoslaissa omana rikostunnusmerkistönään 1.4.2003 voimaan tulleella lailla (61/2003). ${ }^{\mathbf{5}}$ Tätä aikaisemmin rahanpesusta rangaistiin rikoslain 32 luvun 1 §:n

Tapani - To/vanen 2013, s. 197. Ks. myös Matikkala 2005 ja Vihriälä 2012

3 Matikkala 2005, s. 22.

Sahavirta 2008, s. 165

5 Rikoslain 32 luvun 6 §:n nojalla rahanpesusta tuomitaan se, joka ottaa vastaan, käyttää, muuntaa luovuttaa, siirtää, välittää tai pitää hallussaan rikoksella hankittua omaisuutta, rikoksen tuottamaa hyötyä tai näiden tilalle tullutta omaisuutta hankkiakseen itselleen tai toiselle hyötyä, peittääkseen tai häivyttääkseen hyödyn tai omaisuuden laittoman alkuperän tai avustaakseen rikoksentekijää välttämään häivyttääkseen hyödyn tai omaisuuden laittoman alkuperän tai avustaakseen rikoksentekijāa vălttämaaăn rikoksen oikeudelliset seuraamukset. Rahanpesusta tuomitaan saman lainkohdan nojalla myös se, joka tulleen omaisuuden todellisen luonteen, alkuperän, sijainnin tai siihen kohdistuvat määräämistoimet tai oikeudet, tai avustaa toista tällaisessa peittämisessä tai häivyttämisessä. 
2 momentin nojalla kätkemisrikoksena. Nykyisen rahanpesun kriminalisoinnin perusta löytyy Suomelle asetetuista kansainvälisistä velvoitteista. ${ }^{6}$

Rahanpesulla tarkoitetaan toimia, joilla pyritään siirtämään rikoksella hankittu omaisuus tai rikoksen tuottama hyöty lailliseen talousjärjestelmään. Rahanpesutoimien tarkoituksena on saada laittomasti hankitut varat näyttämään laillisilta. ${ }^{7}$ Kyse voi olla periaatteessa millä tahansa rikoksella saadusta omaisuudesta, sillä esirikosten joukkoa ei ole rahanpesussa rajoitettu. Rahanpesun rangaistavuus edellyttää kuitenkin aina sitä, että esirikos on tehty ja sillä on saatu taloudellista hyötyä. ${ }^{\mathbf{8}}$ Esirikoksen tapahtuminen on välttämätöntä, sillä rahanpesutoimet kohdistuvat juuri esirikoksella saatuihin varoihin. Ilman esirikosta varojen alkuperä ei voi siten olla rahanpesusäännöksen edellyttämällä tavalla laiton. ${ }^{9}$ Säännöksessä on asetettu lisäksi vaatimuksia tekijän tahallisuudelle. Tahallisuusvaatimukset ovat osittain erilaiset 1 kohdan tarkoitusta korostavassa ja 2 kohdan seurausta edellyttävässä tekomuodossa, mutta yhteistä niille on se, että tekijän edellytetään kaikissa tapauksissa mieltäneen omaisuuden rikoksella saaduksi tai sen sijaan tulleeksi omaisuudeksi.

Tahallisuus onjaettu Suomen rikosoikeustieteessä kahteen lajiin. Rikoslain yleisten oppien 1.1.2004 voimaan tulleen lainuudistuksen (515/2003) vuoksi rikoslain 3 luvun 6 §:n tahallisuusmääritelmä koskee ainoastaan seuraustahallisuutta, kun taas olosuhdetahallisuuden sisältö jätettiin täsmentymään tarkemmin oikeuskäytännössä. Olosuhdetahallisuuden määrittelemisen koettiin olevan seuraustahallisuutta haastavampaa ja sen vuoksi olosuhdetahallisuuden määritelmää ei otettu lainkaan rikoslakiin. Lakivaliokunta antoi ohjeistukseksi, että olosuhdetahallisuutta arvioitaessa on otettava oikeuskäytännön lisäksi huomioon rikoslain 4 luvun 1 §:n tunnusmerkistöerehdyssäännös. Tähän lainsäädännölliseen ratkaisuun päädyttiin lähinnä sen vuoksi, että lakivaliokunta pelkäsi tahallisuuskynnyksen nousevan talousrikoksissa, jos niiden olosuhdetunnusmerkkeihin sovellettaisiin legaalimääritelmän mukaista todennäköisyystahallisuutta. ${ }^{10}$ Tahallisuusjaottelun vuoksi myös rikostunnusmerkistöt koostuvat seurausta edellyttävistä ja muista tunnusmerkistötekijöistä eli olosuhteista. Rikoslain 32 luvun 6 §:n rahanpesussa rikoksella hankitun omaisuuden laittoman alkuperän häipyminen tai peittyminen on seuraus, kun taas varojen laiton alkuperä on olosuhde." Myös tahallisuus

6 Ks. tarkemmin HE 180/1992 vp, s. 17-19 sekä HE 138/2011 vp, s. 7. Rahanpesua koskevia velvoitteita on asetettu muun muassa Yhdistyneiden Kansakuntien huumausaineiden ja psykotrooppisten aineiden laitonta kauppaa vastaan vuonna 1988 tehdyssä yleissopimuksessa (SopS 44/1994) sekä Euroopan neuvoston rikoksen tuottaman hÿ̈dyn rahanpesua, etsintää, takavarikkoa ja menetetyksi tuomitsemista koskevassa vuoden 1990 y yoissopimuksessa (SopS 53/1994). Myös esimerkiksi Yhdistyneiden Kankakuntien kansa vuodelta 2000 sisältää rahanpesuun liittyviä velvoitteita.

7 Sahavirta 2008 , s. 21-24.

8 HE 53/2002 vp, s. 34 ja 37.

10 LaVM 28/2002 vp, s. 9-10.

11 Näin Sahavirta 2008, s. 173 arvioidaan erikseen jokaisen tunnusmerkistötekijän kohdalla. ${ }^{\mathbf{1 2}}$ Rahanpesussa tämä tarkoittaa sitä, että tahallisuuden arvioinnissa on käytössä käytännössä kaksi tahallisuuden astetta. Varojen laittomaan alkuperään soveltuu olosuhdetahallisuus, jolloin sovellettavana tahallisuuden asteena on todennäköisyystahallisuus, jossa tekijän edellytetään mieltäneen varojen laittoman alkuperän varsin todennäköiseksi. ${ }^{\mathbf{1 3}}$ Todennäköisyystahallisuutta sovelletaan myös seuraukseksi luokiteltavaan varojen peittymiseen ja häipymiseen, kun taas säännöksen 1 kohdan korotettu tahallisuusvaatimus edellyttää tekijältä tarkoitustahallisuutta, joka on tahallisuuden ankarin aste. ${ }^{14}$ Rahanpesutahallisuus edellyttää siten ensinnäkin sitä, että tekijä on ollut tietoinen varojen laittomasta alkuperästä. Tämän lisäksi hänellä on täytynyt olla tarkoitus hankkia itselle hyötyä tai hänen on täytynyt muutoin peittää tai häivyttää rikoksella hankitun omaisuuden alkuperä.

Tarkasteltaessa tekijän tietoisuutta varojen laittomasta alkuperästä kyse on olosuhdetahallisuuden arvioinnista. Tällöin merkitystä onkin erityisesti tiedollisilla kriteereillä. ${ }^{15}$ Niinpä tekijän tekohetkellä oleva tietoisuus varojen laittomasta alkuperästä ratkaisee tahallisuusvaatimuksen täyttymisen. Tekijän tietoisuuden taso olosuhteiden vallitsemisesta on lopulta se, joka määrittelee, onko kyseessä tahallisena rangaistava rahanpesu.

\section{RAHANPESIJÄN TIETOISUUS TUNNUSMERKISTÖN TÄYTTÄVISTÄ OLOSUHTEISTA}

\section{I Tietoisuus tahallisuuden elementtinä rahanpesussa}

Rikoslain 32 luvun 6 §:n rahanpesusäännös sisältää rahanpesun rangaistavuuden edellytykseksi asetetun tahallisuusvaatimuksen, jonka mukaan rahanpesijän on tiedettävä omaisuuden olleen rikoksella hankittua tai rikoksen tuottamaa hyötyä. Tietoisuutta varojen laittomasta alkuperästä edellytetään molemmissa rahanpesun tekomuodoissa. ${ }^{16}$

Tietoisuusedellytys ei ilmene suoraan rikoslain 32 luvun 6 §:n rahanpesusäännöksestä. Aikaisemmin rikoslain 32 luvun 1 §:n kätkemisrikossäännös, jonka perusteella rahanpesusta rangaistiin ennen 1.4.2003 voimaan tullutta lainuudistusta (61/2003), sisälsi lakiin kirjoitetun tietoisuusvaatimuksen. Lainuudistuksessa rahanpesun erilliseen tunnusmerkistöön e

12 Koponen 2007,s.46. Koposen mukaan tunnusmerkistötekijäkohtaista tahallisuuden arviointia vaikeuttaa se, että rikoslain erityisen osan rangaistussäennnöksiä ei ole välttämättä laadittu nin tarkkarajasta 列 Imä edellyttää.

13 Vrt. Sahavirta 2008, s. 172-174, jonka mukaan lainkäyttäjä ei ole olosuhdetahallisuudessa sidottu mihinkään tiettyyn tahallisuuden asteeseen.

14 Ks. korotetusta tahallisuusvaatimuksesta tarkemmin Koponen 2004, s. 232-238 sekä Matikkala 2005, s. 545-546.

15 HE 44/2002 vp, s. 73.

16 Sahavirta 2007, s. 157 
kuitenkaan kirjattu tietoisuusvaatimusta näkyville. ${ }^{17}$ Rikoslain kokonaisuudistuksen vuoksi teot ovat lähtökohtaisesti vain tahallisena rangaistavia. Siksi tuottamuksen rangaistavuus edellyttää säännökseen otettua selkeää mainintaa, eikä yleisiä tahallisuutta ilmentäviä vaatimuksia ole tarpeellista mainita erikseen säännöksissä. ${ }^{18}$ Tästä voidaankin päätellä, että rahanpesijän tietäminen on tavallista tahallisuutta, eikä rahanpesijän tietoisuudelle ole annettavissa erityismerkitystä. ${ }^{19}$ Tämä johtuu siitä, että rikossäännöksissä, jotka sisältävät esimerkiksi maininnan "tietoisena" tai "tietäen", tekijältä edellytetään kvalifioitua tietoa. Tällöin teon rangaistavuus edellyttää korkeampaa tahallisuuden astetta kuin todennäköisyystahallisuutta. ${ }^{20}$ Jos rahanpesijän tietoisuus haluttaisiin ymmärtää erityismerkityksen mukaisesti, edellyttäisi se lakiin kirjattua erillistä mainintaa. Tällaisen nimenomaisen maininnan puuttuessa nykyisestä rahanpesun tunnusmerkistöstä onkin perusteltua ymmärtää rahanpesijän tietämisellä tarkoitettavan tavallista tahallisuuden vaatimusta, mikä rajoittaa erityismerkityksellä operoimista rahanpesun tunnusmerkistöä tulkittaessa.

Rikoslain 32 luvun 6 \&:n rahanpesutunnusmerkistön täyttyminen ei edellytä tekijän tahallisuudelta, että tekijä tietäisi tarkemmin esirikoksen yksityiskohdista. Rahanpesijältä ei edellytetä tarkkaa tietoa esimerkiksi esirikoksen lajista tai siitä, kuka on esirikoksen tekijä tai milloin esirikos on ylipäätään tehty. Sen sijaan tahallisuuden täyttymiseksi riittää, että tekijä on mieltänyt omaisuuden rikoksella hankituksi tai tällaisen omaisuuden surrogaatiksi. ${ }^{21}$ Oikeuskäytännössä tällaisesta tilanteesta oli kyse tapauksessa, jossa syytetty oli lähettänyt ranskalaiselle tulliviranomaiselle rahavaroja sisältävät kaksi kirjettä. Lisäksi hän oli osallistunut kirjeiden laatimiseen allekirjoittamalla ne sekä antamalla käyttöön henkilötietonsa ja tilinumeronsa. Kirjeissä syytetty oli ilmoittanut olevansa 246000 euron suuruisen rahamäärän omistaja ja rahojen olevan peräisin pankkitililtään. Käräjäoikeus katsoi huomattaviin käteisvaroihin kohdistuvan poikkeuksellisen käsittelytavan, syytetyn väittämän häneen kohdistetun uhkan kirjeiden laatimisen yhteydessä sekä sen, että varojen omistajana syytetylle esiintynyt taho ei ollut halunnut tuoda itseään julki, osoittavan omaisuuden olleen rikoksella hankittua tai sen tuottamaa hyötyä, mikä myös syytetyn oli täytynyt mieltää. Käräjäoikeus katsoikin syytetyn osallistuneen kirjeiden laatimiseen tietoisena siitä, että niissä tarkoitettu omaisuus oli rikoksella saatua. ${ }^{22}$ Tahallisuuden täyttymisessä merkitystä ei ollut siis sillä, että esirikoksen tekijää ei ollut saatu selville, eikä tekijä ollut tiennyt varojen olevan peräisin mistään tietystä esirikoksesta.

Jos tahallisuuden vaatimus ulotettaisiin liian yksityiskohtaisiin tietoihin esirikoksesta, rangaistukseen tuomitseminen vaikeutuisi huomattavasti. Tällöin tekijän varojen laitonta

17 HE 53/2002 vp, s. 34.

18 HE 44/2002 vp, s. $73-74$

19 Ks. Matikkala 2005, s. 25

20 HE 44/2002 vp, s. 74 sekä Tapani - Tolvanen 2013, s. 228. Ks. aiheesta myös Frände 2012, s. 129-130

21 Sahavirta 2007, s. 159 sekä Heikinheimo 1998, s. 136

22 Länsi-Uudenmaan käräjäoikeus 17.4 .2015 nro 115766. alkuperää koskevan tietoisuuden toteennäyttäminen saattaisi olla joissakin tapauksissa lähes mahdotonta. ${ }^{23}$ Sen vuoksi pelkkä varojen mieltäminen laittomiksi olosuhteiden perusteella ilman tarkempia esirikokseen liittyviä tietoja mahdollistaa joustavammin teon tahallisena syyksilukemisen.

\subsection{Varojen laiton alkuperä tahallisuuden kohteena}

Tahallisuuden kohteella viitataan siihen, mihin tahallisuuden on ulotuttava tahallisuusvaatimuksen täyttymiseksi. Tahallisuuden kohteena voivat olla tunnusmerkistön mukaiset seuraukset ja olosuhteet. ${ }^{\mathbf{2 4}}$ Olosuhdetahallisuudessa merkitystä on niillä rikosoikeudellisesti relevanteilla seikoilla, jotka toteuttavat muun kuin seuraustunnusmerkin. ${ }^{25}$ Rikoslain 32 luvun 6 s:n rahanpesussa tämä tarkoittaa sitä, että tahallisuuden tulee ulottua muiden rahanpesusäännöksen tunnusmerkistötekijöiden lisäksi varojen laittomaan alkuperään. Tekijän tahallisuuden kohteena on tällöin siis varojen laiton alkuperä.

Tahallisuuden ulottumisessa kaikkiin tunnusmerkistötekijöihin on täsmällisemmin kysymys niin sanotusta peittämisperiaatteesta. Peittämisperiaate edellyttää, että tekijän tahallisuus kattaa koko oikeudenvastaisen teon eli toisin sanoen tekohetken olosuhteet sekä teon seuraukset. ${ }^{26}$ Olosuhteilla tarkoitetaan puolestaan tosiasiallisia ja oikeudellisia seikkoja, joiden on täytyttävä tunnusmerkistön objektiivisen puolen toteutumiseksi. ${ }^{27}$ Rahanpesussa siis vaaditaan, että omaisuus on saatu rikoksella. Varojen laiton alkuperä voikin olosuhteena olla joko olemassa tai vaihtoehtoisesti se ei ole. Olosuhteiden vallitseminen on sinänsä riippumatonta tekijästä ja hänen tahdostaan, eikä rahanpesijä voi sen vuoksi asettaa varojen rikollista alkuperää toimintansa tavoitteeksi. Tämän vuoksi tarkoitustahallisuus ei sovellu olosuhdetahallisuuden muodoksi. Tekijän tahallisuus suhteessa varojen laittomaan alkuperään ratkaistaan siis tiedollisten kriteerien avulla. $^{28}$

Tahallisuuden täyttymisessä merkitystä ei ole sen sijaan tekijän virheellisillä uskomuksilla olosuhteen olemassaolosta. ${ }^{29}$ Jos rahanpesijä uskoo asioiden todellisesta tilasta poiketen

23 HE 180/1992 vp, s. 18. Ks. lisäksi esim. HE 66/1988 vp, s. 106, jonka mukaan kätkemisrikoksissa rangaistavuuden edellytyksenä on se, että omaisuuden omistaja on tiedossa ja esirikoksen tekoaika ja -paikka on riittävästi selvitetty, jotta esirikos voidaan yksilöidä. Sen sijaan teon rangaistavuus e välttämättä edellytä sitä, että tarkka rikoksen tekoaika tai -paikka kyettäisiin ilmoittamaan. Myöskään esirikoksen tekijän ei edellytetä kaikissa tapauksissa olevan tiedossa. Sanottu lähtökohta vaikuttaisi omaksuttaneen myös rahanpesurikoksissa.

24 Matikkala 2005, s. 529-532 sekä s. 544. Tahallisuuden kohteena ovat Matikkalan mukaan siis ne tosiseikat (oliot), se asiantila, joka toteuttaa kyseisen tunnusmerkistön.

25 Tapani - Tolvanen 2013, s. 220

26 Tapani - Tolvanen 2013, s. 198 ja Nuutila 1997, s. 227-232. Ks. peittämisperiaatteesta myös Matikkala 2005, s. 543-571, joka kuvaa peittämisperiaatetta siten, että "subjektiivisen tulee peittää objektiivinen" 27 HE 44/2002 vp, s. 73

28 HE 44/2002 vp, s. 73-74

29 Ks. Koponen 2002, s. 274 
varojen olevan rikoksella saatuja, vaikka ne eivät oikeasti ole, ei rahanpesun tunnusmerkistö voi täyttyä olosuhdetta koskevan tunnusmerkistötekijän puuttumisen vuoksi.

\subsection{Rahanpesijän tietoisuuden ajankohta}

Tahallisuuden täyttymisessä merkitystä on tekijän tietoisuuden ajankohdalla. Kysymys on siitä, milloin peittävyyden on oltava olemassa. ${ }^{\mathbf{3 0}}$ Tietoisuuden ajankohta vaikuttaa siis olennaisesti siihen, onko tekijällä rikoslain 32 luvun $6 \S: n$ edellyttämä tahallisuus.

Lähtökohtana tahallisuuden täyttymisen arvioinnissa on tekijällä olevat tiedot varojen rikollisesta alkuperästä tekohetkellä. ${ }^{31}$ Sinänsä estettä ei ole sille, etteikö arvioinnissa voitaisi ottaa huomioon rahanpesijän tietoisuuteen ennen teon suorittamista kuuluneita tietoja, jos samat tiedot ovat kuuluneet rahanpesijän tietoisuuteen tekohetkelläkin ja ovat siten olleet yhä hänen käytettävissään. Rahanpesijällä ennen tekohetkeä olleet tiedot vaikuttavat ainakin hänen kykyynsä säädellä käyttäytymistään kuten tehdä päätös rahanpesutoimiin ryhtymisestä tai vaihtoehtoisesti pidättyä niiden tekemisestä. ${ }^{32}$ Olennaista tahallisuuden toteutumisessa on siis se, että tekijä on tekohetkellä käsittänyt varojen olevan rikoksella saatuja ja siitä huolimatta ryhtynyt omaisuuteen.

Sen sijaan tahallisuuden täyttymisessä merkitystä ei ole sillä, että tekijän tahallisuus täydentyy vasta teon tekemisen jälkeen. Kysymys on toisin sanoen jälkeenpäin täydentyvästä tahallisuudesta. ${ }^{3 \mathbf{3}}$ Rahanpesussa jälkeenpäin täydentyvä tahallisuus saattaisi tulla kyseeseen esimerkiksi silloin, kun tekijä on ottanut vastaan tai pitänyt hallussaan rikoksella saatuja varoja ja saanut vasta jälkikäteen tietää varojen olevan peräisin rikollisesta menettelystä. Jos rahanpesijällä ei tekohetkellä ollut tietoa siitä, että omaisuus oli rikoksella hankittua, tai rikoksen tuottamaa hyötyä, eikä hän sen vuoksi kyennyt mieltämään varoja rikoksella saaduiksi, ei hänen tahallisuutensa voi siis täyttyä.

30 Matikkala 2005, 531

Matikkala 2005, s. 531

32 Ks. Koponen 2002, s. 299-302. Vrt. kuitenkin Matikkala 2005, s. 531, jonka mukaan niin sanottu etukäteinen tahallisuus (dolus antecedens) ei riitä tahallisuuden kohteen peittymiseen

33 Nuutila 1997, s. 228-229 sekä Frände 2012, s. 108. Jälkeenpäin täydentyvästä tahallisuudesta voidaan käyttää myös nimitystä dolus subsequens.

\section{OLOSUHDETAHALLISUUDEN SISÄLTÖ RIKOSLAIN 32 LUVUN 6 §:N RAHANPESUSSA}

\section{I Tahallisuusmallit ja niiden soveltuminen rahanpesuun}

Olosuhdetahallisuuden oikeustila oli rikoslain vuoden 2004 yleisen osan uudistuksen jälkeen oikeustieteilijöiden keskuudessa pitkään kiistanalainen, ja sen sisällöstä esitettiin eriäviä näkemyksiä. ${ }^{34}$ Olosuhdetahallisuuden alarajalla on merkitystä myös rahanpesussa, koska se määrittää tekijältä edellytettävän tietämisen tason varojen rikollisesta alkuperästä.

Oikeuskirjallisuudessa on esitetty ennen todennäköisyystahallisuusmäärittelyn vakiintumista erilaisia tahallisuusmalleja tahallisuuden ja tuottamuksen välistä rajanvetoa varten. Ne voidaan jakaa mieltämis- ja tahtoteorioihin ${ }^{35}$, jotka korostavat tekijältä vaadittavaa tahallisuutta eri tavalla. Tahtoteorian mukaisessa olosuhdetahallisuuden alarajan määrittelyssä tekijältä vaadittava mieltämisen taso on alempana kuin todennäköisyystahallisuudessa ja merkitystä annetaan myös tekijän hyväksyvälle tai välinpitämättömälle suhtautumiselle. Käytännössä tekijän olosuhdetahallisuus täyttyy tällöin helpommin kuin sovellettaessa todennäköisyystahallisuutta. ${ }^{\mathbf{3 6}}$ Sahavirran mukaan rahanpesurikoksessa tahallisuus täyttyy rikostunnusmerkistön olosuhteiden osalta silloin, kun tekijä suhtautuu hyväksyvästi tai ilmeisen välinpitämättömästi siihen mahdollisuuteen, että hänen vastaanottamansa omaisuus on rikoksella saatua ${ }^{\mathbf{3 7}}$ Samoilla linjoilla on ollut myös Koponen, joka on katsonut, että tahallisuusarvioinnissa merkitystä tulisi antaa tekijän hyväksyvälle tai kvalifioidun välinpitämättömälle suhtautumiselle. ${ }^{\mathbf{3 8}}$ Sen sijaan Tapani ja Tolvanen ovat aikaisemmin kannattaneet olosuhdetahallisuuden määrittelyä varteenotettavana mahdollisuutena pitämisen perusteella. ${ }^{39}$ Toisenlaista näkökantaa on edustanut Frände, jonka mukaan olosuhdetahallisuus olisi kuulunut määritellä niin sanottuna

34 Kysymys olosuhdetahallisuudesta ei ole kuitenkaan enää samalla tavalla epäselvä kuin aikaisemmin sillä korkein oikeus on soveltanut rikoslain yleisen osan uudistuksen jälkeen ainoastaan todennäköisyystahallisuutta olosuhdetahallisuutta koskevissa ratkaisuissaan. Olosuhdetahallisuutta on arvioitu todennäköisyyskriteerin perusteella ratkaisuissa KKO 2006:64, KKO 2010:88, KKO 2012:66, KKO 2013:17, KKO 2013:55, KKO 2014:54 sekä KKO 2015:66.

35 HE 44/2002 vp, s. 73. Ks. aiheesta lisää Matikkala 2005, s. 459-475.

36 Hyttinen 2017, s. 843.

37 Sahavirta 2008, s.174

38 Koponen 2004, s. 112 ja Koponen 2002, s. 283-286.

39 Tapani - Tolvanen 2008, s. 234. Toisin Tapani 2012, s. 613-615, joka on muuttanut kantaansa ja pitää todennäköisyystahallisuutta ainoana loogisesti perusteltavana tahallisuuden ja tuottamuksen välisenä rajanvetomallina. 
tasapainotahallisuutena. ${ }^{\mathbf{4 0}}$ Tahallisuus olisi täyttynyt tasapainotahallisuusmallissakin siis helpommin kuin todennäköisyystahallisuudessa. Matikkala on puolestaan osoittanut, että "varsin todennäköisenä pitämistä" ja "selvillä olon" merkitystä voidaan pitää toisiinsa rinnasteisina, jolloin todennäköisyystahallisuus soveltuu myös tunnusmerkistön olosuhteisiin. ${ }^{41}$

Korkeimman oikeuden ennakkopäätöksillä on huomattava merkitys olosuhdetahallisuuden sisältöä arvioitaessa, koska olosuhdetahallisuudesta ei ole säädetty erikseen laissa. Korkeimman oikeuden ratkaisukäytännöstä voidaankin nyt jo lähes kiistatta päätellä, että todennäköisyystahallisuutta on tarkoitettu sovellettavan rikostunnusmerkistöjen seurausten lisäksi myös olosuhteisiin. Esimerkiksi Tapani on katsonut ratkaisujen KKO 2012:66 sekä KKO 2013:17 vahvistavan, että olosuhdetahallisuuden alaraja määräytyy todennäköisyystahallisuusmallin perusteella. ${ }^{\mathbf{4 2}}$ Vaikuttaa melko selvältä, että sama lähtökohta koskee myös talousrikoksia. Tämä tarkoittaa sitä, että myös rahanpesussa tekijän tahallisuudelta edellytetään, että hän on mieltänyt varojen rikollisen alkuperän yli 50 prosentin todennäköisyydellä. Todennäköisyyskriteerin soveltaminen muihin olosuhteisiin on jokseenkin ristiriidassa lakivaliokunnan mietinnön kanssa, jossa legaalimääritelmän mukaisen todennäköisyystahallisuuden soveltaminen talousrikosten muihin tunnusmerkistötekijöihin pyrittiin välttämään. ${ }^{\mathbf{4 3}}$ Herääkin kysymys, olisiko olosuhdetahallisuudesta voitu jo alun perin säätää rikoslaissa. Hyttisen kantaan siitä, että tämä olisi ollut myös rikosoikeudellisen laillisuusperiaatteen näkökulmasta tyydyttävämpi ratkaisu, on helppo yhtyä. ${ }^{44}$ Jos olosuhdetahallisuuden määritelmä olisi otettu rikoslakiin, olisi tulkintavaikeuksia ja -erimielisyyksiä voitu tässä laajuudessa välttää.

Todennäköisyystahallisuusmallin käyttäminen kaikissa rikostyypeissä on sinänsä perusteltua rikoslain soveltamisen ennakoitavuuden vuoksi. Korkein oikeus on lisäksi todennut ratkaisun KKO 2012:66 perustelujen kohdassa 14 rikosoikeudellisen laillisuusperiaatteen edellyttävän, että tahallisuuden ja tuottamuksen välinen raja ei saa hämärtyä tekijän tietoisuuden mittaamista koskevan tason laskemisen vuoksi. Todennäköisyystahallisuuden perusteella tehtävää olosuhdetahallisuuden alarajan määrittelemistä kritisoitiin aikaisemmassa oikeuskirjallisuudessa etenkin sen vuoksi, että tällöin tarkoituksellisesti tietämättömästi menettelevän tekijän

40 Ks. Frände 2005, s. 131-136 sekä Frände 2012, s. 127. Frände on päätynyt tasapainotahallisuusmalliin koska hänen mukaan tunnusmerkistöerehdyssäännöksen "olla selvillä" -vaatimusta ja "varsin todennäköinen" -kriteeriä ei olisi tarvinnut rinnastaa toisiinsa. Rahanpesussa tekijä olisitällöin menetellyt tahallaan, jos hän olisi pitänyt yhtä todennäköisenä vaihtoehtona sitä, että varat ovat rikoksella saatuja kuin sitä, että ne eivät ole peräisin rikollisesta menettelystă

41 Matikkala 2007, s. 110-111.

42 Ks. tarkemmin Tapani 2012, s. 607-619 ja Tapani 2013, s. 786-798.

43 LaVM 28/2002 vp, s. 9-10.

44 Ks. Hyttinen 2016, s. 919 tuomitseminen saattaisi vaikeutua huomattavasti tai joissakin tilanteissa jopa estyä kokonaan. ${ }^{\mathbf{4 5}}$ Vaikka todennäköisyystahallisuudessa tahallisena rangaistavan menettelyn taso onkin korkeammalla kuin tahtotahallisuudessa, ei rahanpesun tahallisuusarvioinnissa ole kysymys kuitenkaan rangaistavan ja rankaisemattoman menettelyn välisestä rajankäynnistä ${ }^{\mathbf{4 6}}$, koska rahanpesu on säädetty rangaistavaksi myös tuottamuksellisena. Sen vuoksi tekijä ei välttämättä vapaudu kokonaan rangaistusvastuusta, vaikka tahallisuus ei yltäisikään todennäköisyystahallisuuden tasolle. Tällöin syyksilukemistilanteet eivät ole niin ongelmallisia kuin ehkä joissakin muissa rikostyypeissä saattaisivat olla tällaisessa tilanteessa.

Vasta-argumentaatio todennäköisyystahallisuuden soveltumisesta joidenkin rikostyyppien olosuhdetahallisuuteen saattaisi olla mahdollista ainoastaan sillä perusteella, että korkein oikeus ei ole antanut vielä talousrikosten ydinalueelle sijoittuvaa ratkaisua olosuhdetahallisuudesta. ${ }^{\mathbf{4 7}}$ Lisäksi voidaan kiinnittää huomiota siihen, että korkein oikeus totesi yrityssalaisuuden väärinkäyttöä koskevan ratkaisun KKO 2013:17 perustelujen kohdassa 33, että tekijän tahallisuuden tarkastelua jollakin muulla tavalla kuin todennäköisyystahallisuuden perusteella ei voida sulkea täysin pois tilanteiden monimuotoisuuden vuoksi. Kuitenkin korkein oikeus totesi jäljempänä samassa perustelujen kohdassa, että tahallisuuden alarajaa ei saa asettaa korkeimman oikeuden ratkaisukäytännössä vakiintuneesta tasosta alemmaksi siten, että se merkitsisi tosiasiassa rangaistavuuden alan laajentamista. Tästä lausumasta päätellen jonkin muun rajanvetoteorian kuin todennäköisyystahallisuuden soveltamisen mahdollisuutta on pidetty epätodennäköisenä ja lähestulkoon teoreettisena. ${ }^{\mathbf{4 8}}$

Sanottu lähtökohta, jonka mukaan todennäköisyystahallisuutta alemman rajanvetoteorian soveltamisen mahdollisuus on vain teoreettinen, koskee myös rahanpesua. Tähän näkökantaan voidaan hakea lisätukea lakivaliokunnan mietinnöstä, jonka mukaan rahanpesusta olisi kysymys silloin, jos kuluttamiseen osallistuva esirikoksen tekijän lähipiiri tietää tai pitää varsin todennäköisenä, että varat ovat rikoksella saatuja. ${ }^{49}$ Lakivaliokunnan mietinnöstä voidaan päätellä, että todennäköisyystahallisuutta alemmat tahallisuuden asteet eivät sovi rahanpesun

45 Ks. esim. Koponen 2004, s. 112-115 sekä Sahavirta 2008, s. 174. Korkein oikeus on kuitenkin linjannut ratkaisukäytännössään, että tarkoituksellinen tietämättömyys tunnusmerkistön täyttävistä olosuhteista ei poista tahallisuutta rikoslain 4 luvun 1 §:n nojalla, eikä sen kaltaista tietämättömyyttä ole näin ollen perusteltua tulkita siten, että se johtaisi tekijän kannalta edulliseen lopputulokseen. Tekijän tuomitseminen ei siis esty, vaikka hän olisi menetellyt tarkoituksellisesti tietämättömästi ja hän ei ol sen vuoksi pitänyt olosuhteiden käsilläoloa varsin todennäköisenä. Ks. esim. KKO 2006:64, kohta 7 .

46 Ks. Koponen 2007, s. 43, jonka mukaan talousrikoksissa vaihtoehtoina ovat yleensä joko teon tahallisena syyksilukeminen tai kokonaan rankaisematta jättäminen. Koposen kritiikki kohdistuu siis siihen, että todennäköisyystahallisuusmallin soveltaminen voi johtaa ongelmallisiin tilanteisiin niiden rikosten kohdalla, joiden tuottamuksellista tekomuotoa ei ole kriminalisoitu.

47 Tapani 2013, s. 798

48 Tapani 2013 s. 794

49 LaVM 31/2010 vp, s. 2 
olosuhdetahallisuuden alarajaksi. Kysymys on siis tuottamuksellisesta rahanpesusta, jos tekijän mieltäminen varojen laittomasta alkuperästä ei yllä varsin todennäköisenä pitämisen tasolle. Näin ollen tietoisuutta ja tahallisuutta arvioidaan rahanpesussakin sen mukaan, onko tekijä pitänyt varsin todennäköisenä, että omaisuus on rikoksella saatua tai rikoksen tuottamaa hyötyä. ${ }^{\mathbf{5 0}}$

\subsection{Rahanpesijän tietoisuusvaatimuksen ja rikoslain 4 luvun I §:n tunnusmerkistöerehdyssäännöksen välinen suhde}

Tunnusmerkistöerehdyksestä on säädetty rikoslain 4 luvun $1 \S$ :ssä. Kysymys on vastuuvapausperusteesta, joka sulkee tietyin edellytyksin tahallisuuden pois. Se on ikään kuin tahallisuuden kääntöpuoli. ${ }^{51}$ Tunnusmerkistöerehdyksellä ei ole vaikutusta teon huolimattomuuteen, joten rahanpesu voitulla rangaistavaksi silti tuottamuksellisena, vaikka tunnusmerkistöerehdyssäännös olisi poistanut tahallisuuden.

Erehtyminen tarkoittaa tiedon puutetta ja väärää tietoa. ${ }^{52}$ Tunnusmerkistöerehdyksen soveltamistilanteet voidaankin jakaa kahteen ryhmään. Tunnusmerkistöerehdys poistaa tekijän tahallisuuden ensinnäkin silloin, kun tekijä ei ole ollut selvillä niiden seikkojen olemassaolosta, joita rikoksen tunnusmerkistön toteutuminen edellyttää. Selvillä oloa tulkitaan yhdenmukaisesti olosuhdetahallisuuden alarajan määräytymisen kanssa, joten rahanpesussa tekijä ei ole selvillä varojen laittomasta alkuperästä silloin, kun hän ei ole pitänyt varojen laittoman alkuperän olemassaoloa varsin todennäköisenä. Toinen tunnusmerkistöerehdyksen soveltamistilanne koskee puolestaan tapauksia, joissa tekijä puhtaasti erehtyy niiden seikkojen olemassaolosta, joita rikoksen tunnusmerkistön toteutuminen edellyttää. ${ }^{\mathbf{5 3}}$ Rahanpesussa tekijä siis erehtyy siitä, ovatko varat rikoksella hankittuja. Tiedolliset vaatimukset ratkaistaan lähtökohtaisesti tahallisuusoppien avulla. Sen sijaan erehdysoppien soveltamiseen turvautumisen on katsottu olevan tarpeellista ainoastaan poikkeuksellisesti. ${ }^{\mathbf{5 4}}$

Oikeuskäytännössä syytetyn katsottiin erehtyneen, kun hän oli etsinyt kokopäivätyönsä ohelle lisätyötä ja ottanut yhteyttä internetissä olleen työpaikkailmoituksen perusteella käytettyjen autojen ja varaosien myyntiä harjoittaneeseen yhtiöön. Syytetty oli useiden puhelinkeskustelujen jälkeen palkattu yhtiön rahaliikenteenhoitajaksi ja hänen tehtävikseen olivat tulleet rahansiirrot yhtiön eri maissa oleville myyntiedustajille sekä rahansiirroista tehtävä kirjanpito ja raportoiminen yhtiölle. Yhtiö oli ilmoittanut rahansiirtojen suuruudeksi 1 000-10 000 euroa, joista vastaajalle maksettaisiin 5 prosentin palkkio. Syytetyn tehtävänä ol

50 Näin myös Tapani 2014, s. 727

51 LaVM 28/2002 vp, s. 10

52 HE 44/2002 vp, s. 105

53 Ks. Tapani - Tolvanen 2013, s. 238-241.

54 Näin Koponen 2007, s. 45. kuitenkin itse huolehtia veron maksamisesta suoritetusta palkkiosta. Lisäksi työsopimuksen ehtona oli, että auton ostaja siirtää syytetyn tilille rahan, jonka syytetty puolestaan siirtää yhtiön myyntiedustajalle. Tätä varten syytetty oli avannut pankkitilin, johon välitettävä raha voitiin siirtää. Pian työsopimuksen solmimisen jälkeen syytetylle olikin ilmoitettu, että auton ostaja siirtää hänen tililleen rahaa, joka syytetyn tulee siirtää myyntiedustajalle. Syytetty oli tämän jälkeen siirtänyt kyseisen rahasumman toiselle tililleen ja sieltä Western Unionin kautta Ukrainaan kahdelle henkilölle, joiden hän oli uskonut olevan yhtiön myyntiedustajia. Syytetty oli kuitenkin alkanut epäillä tulleensa erehdytetyksi, kun häneen oltiin oltu yhteydessä pankista, eikä hän ollut enää saanut yhteyttä yhtiön edustajaan. Käräjäoikeus katsoi, että työsopimuksen tekemiseen ei sinänsä liittynyt mitään tavanomaisesta poikkeavaa. Syytetyllä ei ollut myöskään syytä epäillä työsopimuksen aitoutta, koska tehty rahasiirto oli vastannut työsopimuksessa sovittuja tehtäviä. Näin ollen syytetyn ei katsottu mieltäneen lähettämiensä rahojen olleen rikoksella saatuja ja syyte rikoslain 32 luvun 6 §:n rahanpesusta hylättiin. ${ }^{\mathbf{5 5}}$

Tunnusmerkistöerehdyksen soveltamistilanteista on syytä erottaa tapaukset, joissa tekijä menettelee tarkoituksellisesti tietämättömästi suhteessa varojen laittomaan alkuperään rikosvastuun välttämiseksi. Korkein oikeus on linjannut törkeää huumausainerikosta ja sukupuolisiveellisyyttä loukkaavan kuvan levittämistä koskevissa ratkaisussaan KKO 2006:64 ja KKO 2013:55, että tunnusmerkistöerehdys ei poista tekijän tahallisuutta tilanteissa, joissa tekijä ei ole tarkoituksellisesti tai laista johtuvan selvitysvelvollisuuden laiminlyönnin vuoksi ollut selvillä olosuhteista. Vastaavanlainen tietämättömyys varojen laittomasta alkuperästä ei rahanpesussakaan voi tulla siis kyseeseen rikoslain 4 luvun $1 \S: n$ tunnusmerkistöerehdyksenä.

\subsection{Selonottovelvollisuus rahanpesussa ja sen laiminlyönti}

Tahallisena rangaistavaan rahanpesuun liittyy myös tekijän omaisuuden alkuperää koskeva selonottovelvollisuus. ${ }^{\mathbf{5 6}}$ Rahanpesijän selonottovelvollisuudesta ei ole säädetty erikseen laissa, mutta oikeuskäytännössä tekijältä on toisinaan edellytetty omaisuuden alkuperään liittyviä selvittämistoimia

Tulkintatukea rahanpesijän selonottovelvollisuudelle voidaan hakea esimerkiksi väärennystä koskevista rikoslain 33 luvun 1 §:n esitöistä. Väärennyksessä tahallisuuden täyttyminen edellyttää tekijän tietoisuutta todistuskappaleen epäaitoudesta. Lain esitöissä viitataan tilanteisiin, joissa väärennetyn asiakirjan esittänyt henkilö usein kiinnijäämisen jälkeen väittää toimineensa hyvässä uskossa tuntemattoman miehen puolesta, jolta hän on saanut asiakirjan Todistuskappaleen käyttäjälle onkin asetettu tällaisia tilanteita silmällä pitäen yleiseen

55 Espoon käräjäoikeus 29.8.2014 nro 134991

56 Ks. Heikinheimo 1998, s. 139-141, joka pohtii, voidaanko rahanpesijälle asettaa selonottovelvollisuus varojen alkuperästä. Hän patyy kuitenkin silloisen oikeuskaytannon ja -k lopputulokseen, jonka mukaan kysymykseen on mahdotonta vastata. 
elämänkokemukseen perustuva selonottovelvollisuus. ${ }^{\mathbf{5 7}}$ Lähtökohtaisesti rahanpesussakin tekijän selonottovelvollisuus voitaneen kytkeä yleiseen elämänkokemukseen. Tällöin voidaan nähdäkseni lähteä siitä, että tekijän on pyrittävä varmistumaan omaisuuden alkuperästä aina, kun hän voi yleisen elämänkokemuksen perusteella havaita olosuhteissa olevan jotain epäilyttävää tai poikkeuksellista.

Oikeuskäytännössä ammattimaista jalometallikauppaa harjoittaneella henkilöllä katsottiin olevan velvollisuus selvittää vastaanottamiensa jalometallien alkuperä. Selonottovelvollisuuden olemassaoloa tukivat tapauksessa elinkeinotoiminnan harjoittajan aseman lisäksi tapauksessa vallinneet epäilyttävät kaupanteko-olosuhteet. Epäilyttävillä olosuhteilla hovioikeus viittasi ammattimaisen jalometallikauppiaan tietoisuuteen jalometallien myyjän rikollisesta menneisyydestä sekä siihen, että jalometallien myyjä ei ollut suostunut kaupantekoon muutoin kuin käteistä vastaan sekä ilman kuittia. Perusteluissaan hovioikeus ei katsonut riittäväksi jalometallikauppiaan internetissä sekä tuttavilleen esittämiä kyselyjä siitä, oliko omaisuus mahdollisesti anastusrikoksella hankittua. Tietoisuutta jalometallien laittomasta alkuperästä puoltavina seikkoina pidettiin myös sitä, että jalometallikauppias ei ollut varmistanut jalometallien alkuperää poliisilta eikä kultasepältä, jonka velkojen panttina hän oli arvellut jalometallien olleen. Hovioikeuden mukaan tapauksessa voitiin edellyttää, että hän olisi epäilyttävien kaupantekoolosuhteiden sekä jalometallien suuren määrän vuoksi tällaiset varmistukset tehnyt, vaikka olisi pitänyt myyjän kertomusta omaisuuden alkuperästä lähtökohtaisesti uskottavana. ${ }^{\mathbf{5 8}}$ Tämän perusteella tahallisuus voinee siis täyttyä jonkinasteisista alkuperän varmistuksista huolimatta, jos hän on kuitenkin tekohetkellä vallinneiden olosuhteiden vuoksi voinut päätellä omaisuuden olleen rikoksella saatua. Kun tekijällä on ollut tietty yksilöity velvollisuus varmistua seikkojen oikeasta asiantilasta, hänen selonottovelvollisuutensa voidaan katsoa olevan sitä korkeammalla, mitä merkityksellisemmästä ja yksilöidymmästä tiedosta on kysymys. Ainakin liike-elämässä toimivalla on jo lähtökohtaisesti velvollisuus tietää esimerkiksi toimialaansa koskevasta lainsäädännöstä tai taloudellisesta asemastaan. ${ }^{\mathbf{5 9}}$

Hyttisen mukaan selonottovelvollisuuden korostaminen on kriminaalipoliittisesta näkökulmasta perusteltua, ja se mahdollistaa olosuhdetahallisuutta koskevien ratkaisujen tekemisen joustavasti. ${ }^{60}$ Tähän kantaan on helppo yhtyä, sillä tekijän tahallisuus voidaan Hyttisen osoittamalla tavalla perustaa tarvittaessa selonottovelvollisuuden laiminlyöntiin, vaikka hän ei olisi mieltänytkään varojen rikollista alkuperää varsin todennäköiseksi. Tahallisuuden täyttymiseksi on tällöin riittävää, että rahanpesijä on laiminlyönyt omaisuuden

57 HE 66/1988vp, s. 113.

58 Turun hovioikeus 13.12017 nro 101426

59 Koponen 2004, s. 118-120. Koposen mukaan selonottovelvollisuus olisi ollut paremmin yhteen sovitettavissa tekijän hyväksyvän tai kvalifioidun välinpitämättömän suhtautumisen kuin todennäköisyystahallisuuden kanssa.

60 Hyttinen 2016, s. 927 alkuperää koskevat selvittämistoimet. Selonottovelvollisuuden korostaminen on tärkeää etenkin tilanteissa, joissa tekijä on pyrkinyt tarkoituksellisesti välttämään rikosvastuun. Hyttinen huomauttaa kuitenkin osuvasti, että selonottovelvollisuuden korostamisen seurauksena olosuhdetahallisuudella ei ole enää tosiasiallista alarajaa. Perustettaessa tekijän tahallisuusvastuu selonottovelvollisuuden laiminlyöntiin, häneltä ei siis edellytetä varsinaisesti olosuhdetahallisuuden alarajana olevaa "varsin todennäköiseksi mieltämistä" varojen laittomasta alkuperästä. Merkitystä on ennen kaikkea sillä, onko hän pyrkinyt selvittämään varojen alkuperän. ${ }^{61}$ Teko voidaan syyksi lukea tällöin joko tekijän passiivisen menettelyn perusteella tai vaihtoehtoisesti tekijä voi joissakin tilanteissa vapautua vastuusta, jos hän on pyrkinyt riittävästi selvittämään varojen alkuperää.

\section{OLOSUHTEISTA PÄÄTELTÄVÄN RAHANPESIJÄN TIETOISUUDEN TOTEENNÄYTTÄMINEN}

Rikoslain 32 luvun 6 §:n rahanpesussa tekijän tahallisuus päätellään teon olosuhteista. ${ }^{62}$ Syynä tahallisuusarvioinnin perustamiselle lähtökohtaisesti objektiivisten tosiseikkojen varaan on ollut käytännössä ennakoitavat näyttöongelmat. ${ }^{63}$ Tekijän tahallisuutta arvioitaessa huomiota kiinnitetään seikkoihin, jotka osoittavat hänen tietoisuutensa yltävän "varsin todennäköisenä pitämisen" tasolle. Tuomioistuimet tukeutuvat lisäksi tahallisuusvaatimuksen täyttymistä arvioidessaan usein pakottavaan päättelyyn, jossa ratkaistaan, mitä tekijän on täytynyt käsittää tai ymmärtää olosuhteiden perusteella. ${ }^{64}$

Tekijä saattaa ensinnäkin mieltää varojen olevan rikoksella saatuja hänellä esirikoksen tekijästä olevien tietojen perusteella. ${ }^{65}$ Näin oli esimerkiksi ratkaisussa, jossa tahallisuuden katsottiin täyttyvän, kun syytetty oli antanut esirikoksen tekijän siirtää yhteensä 8955 euroa huumausainekaupasta saatuja varoja tililleen. Tämänjälkeen syytetty oli nostanut tilille siirretyt varat käteisenä ja luovuttanut käteisvarat esirikoksen tekijälle. Tahallisuuden täyttymistä puolsi tapauksessa se, että syytetty oli ollut tietoinen esirikoksen tekijän pääosin eläkkeestä ja lainaamalla kertyvistä tuloista sekä siitä, että esirikoksen tekijä oli velkajärjestelyssä. Lisäksi tahallisuuden täyttymistä tuki se, että syytetty tiesi esirikoksen tekijän harjoittamasta huumausainekaupasta, koska hän oli aikaisemmin itsekin välittänyt huumausaineita tämän puolesta. ${ }^{66}$ Ratkaisusta voidaan päätellä, että rahanpesijällä olevat tiedot esirikoksen tekijän taloudellisesta asemasta, kuten velkajärjestelyssä olemisesta ja tulojen muodostumisesta

61 Hyttinen 2016, s. 928-929, joka pohtii myös sitä, onko olosuhdetahallisuuden alaraja ennemmin pelkkää retoriikkaa vai tuomioistuimia tosiasiassa sitova ohje.

62 Sahavirta 2007, s. 162

63 Sahavirta 2008, s. 169

64 Neira-Perämaa-Vasara 2003, s. 30-31.

65 Näin Neira - Perämaa - Vasara 2003, s. 32

66 Lapin käräjäoikeus 10.10.2014 nro 143076. 
lähinnä yhteiskunnan tuista, sekä tietoisuus esirikoksen tekijän rikollisesta elämäntyylistä, voivat osoittaa tekijän tietoisuutta varojen laittomasta alkuperästä. Tietoisuutta saattaisi joissakin tapauksissa osoittaa myös tekijällä oleva tieto esirikoksen tekijän luottotietojen menettämisestä, joka kuvastaa esirikoksen tekijän taloudellista asemaa. Näiden tietojen perusteella tekijä voi ainakin varmemmin mieltää varat rikoksella saaduiksi.

Tahallisuuden täyttymistä tukee myös rahanpesijän tietoisuus esirikoksen tekijän aikaisemmasta rikostuomiosta. Näin oli korkeimman oikeuden ratkaisussa KKO 2009:59, jossa rahanpesun esirikoksena oli törkeä huumausainerikos. Tapauksessa perheen käyttöön oli hankittu 42000 euron arvoinen auto sekä 7700 euron arvoinen mönkijä, joita oli maksettu osamaksuilla. Lisäksi perheen tileille oli tehty käteispanoja yhteensä 12917 euron verran. Sekä esirikoksen tekijä että hänen syytettynä oleva avopuolisonsa olivat eläneet yhteiskunnan tuilla, eikä heillä ollut muita laillisia tulonlähteitä. Perheen käteisvaroja oli säilytetty kassakaapissa ja tilillepanoja oli suoritettu silloin, kun perheellä oli ollut laskuja maksettavana. Esirikoksen tekijä oli maksanut käteisvaroilla muun muassa perheen lomamatkan Thaimaahan sekä antanut syytetylle käteisvaroja päivittäisiin kulutusmenoihin. Syytetyn tietoisuutta varojen laittomasta alkuperästä osoitti korkeimman oikeuden mukaan se, että hän oli tiennyt esirikoksen tekijän aiemmin huumausainerikoksesta saamasta tuomiosta. Lisäksi syytetyn oli täytynyt käsittää, että sosiaalietuuksilla eläneen perheen käyttöön lyhyessä ajassa tullut suuri määrä käteisvaroja on ollut peräisin rikollisesta menettelystä. Näiden seikkojen perusteella korkein oikeus katsoi syytetyn olleen tietoinen varojen laittomasta alkuperästä. Hieman samansuuntaisesti tahallisuusarvioinnissa tietoisuutta varojen laittomasta alkuperästä tukevana seikkana voitaneen ottaa huomioon myös se, että rahanpesijä on tiennyt esirikoksen tekijän olleen vankilassa. ${ }^{\mathbf{6 7}}$

Läheissuhde on ulkoisesti havaittava olosuhde, johon voidaan kiinnittää huomiota tahallisuusarvioinnissa. ${ }^{68}$ Kyse voi olla esimerkiksi avio- tai avopuolisoiden välisestä suhteesta tai vanhempien ja lasten välisestä suhteesta. Sen perusteella voidaan toisinaan päätellä, että tekijä on tiennyt varojen laittomasta alkuperästä paremmin kuin täysin ulkopuolinen henkilö. Oikeuskäytännössä tahallisuuden katsottiin täyttyvän, kun syytetyt olivat ottaneet esirikoksen tekijältä vastaan maksuvälinepetoksella saatuja varoja yhteensä 4000 euron verran. Käräjäoikeus katsoi syytettyjen ja esirikoksen tekijän välisen läheissuhteen perusteella olevan todennäköistä, että syytetyt olivat tunteneet esirikoksen tekijän taloudellisen tilanteen sekä sen, että esirikoksen tekijän heidän tileilleen siirtämä rahamäärä on ollut huomattava hänen tavanomaisiin käyttövaroihinsa nähden. Toisena tahallisuutta tukevana seikkana tapauksessa oli se, että syytetyt olivat olleet pankissa rahansiirtojen tapahtuma-aikaan eikä rahansiirroille ollut olemassa asiallista syytä. ${ }^{69}$ Syytetyn ja esirikoksen tekijän läheinen suhde ei kuitenkaan välttämättä aina tarkoita sitä, että syytetyllä olisi tosiasiassa tietoa varojen laittomasta alkuperästä. Oikeuskäytännössä tahallisuusvaatimuksen ei nimittäin katsottu täyttyneen, kun tytär oli ottanut peliriippuvaiselta äidiltään vastaan kavallus- ja kirjanpitorikoksilla saatuja varoja reilun 10 vuoden ajan. Tapauksessa esirikoksen tekijän tytär oli täyttänyt 19 vuotta vuonna 2001 ja ollut esirikoksen tekijän ainoa lapsi. Lisäksi hänen terveydentilansa ja ansaintamahdollisuutensa eivät olleet tuohon aikaan kovin hyvät. Käräjäoikeus lähti perusteluissaan siitä, että vanhemman tekemät tulonsiirrot omalle lapselle tavanomaisessa elatus- ja avustusmielessä eivät lähtökohtaisesti täytä rahanpesutunnusmerkistöä, eikä tyttären terveydentilan vuoksi huomattavaakaan taloudellista avustamista lähtökohtaisest voida pitää epätavanomaisena. Käräjäoikeus viittasi ratkaisussaan tyttären tahallisuuden poissulkevana tekijänä myös tehtyjen tilisiirtojen tavanomaisuuteen kertasuorituksina ja vuositasolla, joita melko hyvin palkatussa työssä käyvä henkilö tavallisesti pystyy suorittamaan. Lisäksi käräjäoikeus tukeutui kokemussääntöihin todetessaan jo "yleisen elämänkokemuksen" perusteella olevan mahdollista, että pitempään työelämässä olleelle henkilölle on voinut kertyä säästöjä, joiden vuoksi suorituksia ei voitu pitää poikkeuksellisina osapuolten asemiin nähden. Käräjäoikeuden mukaan ulkopuolisella henkilöllä tai välttämättä edes läheiselläkään henkilöllä ei ollut mahdollisuutta tehdä päätelmiä tyttären äidillä olleen rikollisia tulolähteitä tai menoeriä. ${ }^{70}$

Rahanpesijän ja esirikoksen tekijän läheinen suhde ei siis kaikissa tapauksissa tarkoita sitä, että rahanpesijä voisi mieltää varat rikoksella saaduiksi. Tällöinkin tapauksessa vallinneilla muilla teko-olosuhteilla ja tekijällä tiedossa olleilla seikoilla on merkitystä tahallisuuden täyttymisessä. Vertailtaessa esimerkiksi jälkimmäistä ratkaisua sitä edeltäneisiin kahteen ratkaisuun, joissa muiden seikkojen ohella läheissuhteeseen kiinnitettiin huomiota tahallisuusarvioinnissa, voidaan havaita, että teko-olosuhteet olivat näissä kahdessa muussa ratkaisussa erilaiset muun muassa epätavallisten järjestelyiden vuoksi. Lisäksi molemmissa tapauksissa tekijät olivat tienneet joko esirikoksen tekijän taloudellisista vaikeuksista tai aikaisemmasta rikostuomiosta. Sen sijaan jälkimmäisessä tapauksessa kysymys oli sinänsä normaalista tyttären taloudellisesta avustamisesta, jota vanhemmat voivat lähtökohtaisesti tehdä ilman, että se herättää epäilyksiä toiminnan laittomuudesta. Tapauksen teko-olosuhteet olivat siis hyvin tavanomaiset eikä tyttärellä ollut tietoa äitinsä rikollisista toimista, joiden perusteella hän olisi voinut päätellä varojen olleen rikoksella hankittuja. Sen vuoksi tahallisuuden täyttymättä jääminen kyseisessä tapauksessa oli perusteltua.

Tahallisuusvaatimuksen täyttymistä arvioitaessa voidaan kiinnittää huomiota muihinkin objektiivisesti havaittaviin seikkoihin kuten tekijän toimien epätavallisuuteen tai toiminnan poikkeuksellisuuteen yleensäkin. ${ }^{71}$ Tahallisuuden katsottiin täyttyvän esimerkiksi tapauksessa, jossa syytetyn tilille oli siirretty törkeällä petoksella saatuja varoja, minkä jälkeen syytetty oli

70 Helsingin käräjäoikeus 19.12.2014 nro 156229

71 Ks. myös Neira - Perämaa - Vasara 2003, s. 34-36. 
nostanut kyseiset varat tililtä kuudella automaattinostolla sekä loppuosan varoista kahdella käteisnostolla. Käräjäoikeus katsoi, että laillisessa toiminnassa kyseiselle menettelylle, jossa rahavaroja kierrätetään toisen henkilön tilin kautta ja välittömästi talletusten jälkeen nostetaan rahavarat pois tilitä, ei ole mitään järkevää perustetta. Lisäksi käräjäoikeus otti huomioon syytetyn tahallisuuden olemassaoloa puoltavana tekijänä sen, että syytetty oli nostanut osan varoista ulkomaanvaluuttana. ${ }^{\mathbf{7 2}}$ Ratkaisusta voitaneen päätellä, että tekijän suorittamat poikkeukselliset tilisiirrot ja -nostot voivat osoittaa hänen tienneen omaisuuden olleen rikoksella saatua. Myös tilin antaminen tuntemattoman henkilön käyttöön voi osoittaa tekijän tietoisuutta varojen laittomasta alkuperästä. Oikeuskäytännössä on esimerkiksi katsottu, että rahanpesijän oli täytynyt tietää rahojen olevan peräisin rikollisesta menettelystä, kun hän oli suostunut torilla entuudestaan tuntemattoman henkilön ehdotukseen, jossa rahanpesijä antaa tilinumeronsa ja tämän jälkeen hänen tilille siirretään rahaa. Lisäksi rahanpesijälle oli luvattu järjestelystä 400 euron palkkio. ${ }^{73}$

Syytetyn on katsottu olleen tietoinen varojen laittomasta alkuperästä myös tapauksessa, jossa hänen liiketoimintansa tarkoituksena oli siirtää yhteistyökumppaneidensa saatavat Viroon käteiseksi muuttamista varten. Varojen siirtäminen oli toteutettu siten, että syytetty oli laatinut kolmen muun yhtiön nimissä laskut yhteistyökumppaneidensa urakkasaatavista. Tahallisuuden katsottiin täyttyvän sillä perusteella, että laillisesti toimivilla ja lakisääteisiä velvoitteita noudattavilla yhtiöillä ei olisi ollut tarvetta salata työurakoitaan, vaan ne olisivat voineet itse perustaa yhtiön tai laskuttaa urakan omalla nimellä. ${ }^{74}$ Toisessa tapauksessa syytetyn katsottiin olleen tietoinen miehensä elinkeinotoimintaan liittyvistä veropetosrikoksilla saaduista varoista, kun hän oli huolehtinut käytännössä kaikesta elinkeinotoiminnan rahaliikenteestä. Tahallisuuden täyttymistä tuki lisäksi se, että verovirasto oli syytetylle aikaisemmin lähettämässään selvityspyynnössä antanut yksityiskohtaista informaatiota elinkeinotoimintaan liittyvästä kirjanpito- ja ilmoittamisvelvollisuudesta. Syytetyn katsottiin tämän seikan sekä jo yleisen elämänkokemuksen perusteella täytyneen tietää, että elinkeinotoiminnasta saaduista tuloista on maksettava veroa. Lisäksi syytetyn oli täytynyt myös havaita, että veronmaksuvelvollisuus oli kyseisessä elinkeinotoiminnassa täysin laiminlyöty. ${ }^{75}$ Sen sijaan tahallisuuden ei katsottu täyttyneen tapauksessa, jossa tekijä oli antanut paikkansapitämättömän esitutkintakertomuksen esirikoksen tekijän kiinteistökauppaan ja sen rahoittamiseen liittyvistä seikoista. Virheellisen esitutkintakertomuksen antamista ei pidetty riittävänä näyttönä tekijän tietoisuudesta, koska hänellä oli ollut perusteltu syy uskoa kiinteistön olleen rahoitettu pelivoitoilla. Tätä tuki erityisesti se seikka, että tekijä tiesi ulosottoviraston aikaisemmin hyväksyneen riittäväksi selvityksen siitä, että kiinteistön kauppahinta oli maksettu pelivoitoista saaduilla varoilla. ${ }^{\mathbf{7 6}}$

72 Pirkanmaan käräjäoikeus 9.6.2017 nro 12386

73 Pirkanmaan käräjäoikeus 27.3.2015 nro 11428

74 Vaasan hovioikeus 11.1.2013 nro 21.

75 Pohjois-Karjalan käräjäoikeus 28.9.2012 nro 1757.

76 Jyväskylän käräjäoikeus 4.12.2009 nro 2548.
Toisentyyppisessä tapauksessa arvioitiin vastaajien tietoisuutta anastusrikoksilla saadun omaisuuden alkuperästä. Tapauksessa vastaajien $X j a$ Y tietoisuutta anastusrikoksilla saaduista elektroniikkalaitteista osoitti ensinnäkin se, että laitteita oli luovutettu melko kaukana Helsingin keskustasta sijaitsevilla parkkipaikoilla, jonne vastaajat ja esirikoksen tekijä olivat erikseen sopineet tapaamiset, vaikka he olivat tavanneet jo aikaisemmin samana päivänä joko laivalla tai satamassa. Käräjäoikeus hyödynsi siis myös tässä tapauksessa toiminnan epätavallisuutta tahallisuuden täyttymistä tukevana seikkana. Lisäksi vastaajan $X$ tietoisuutta arvioitaessa otettiin huomioon myös se seikka, että hän oli syyllistynyt avunantoon esirikoksen tekijän suorittamaan törkeään varkauteen ja kieltäytynyt tämän jälkeen kuljettamasta iPad-laitteita sisältävää kassia autossaan. Vastaajan $Y$ tietoisuutta arvioitaessa huomiota kiinnitettiin Y:n väitteeseen, jonka mukaan elektroniikkalaitteiden hinta ei ollut normaalihintaa paljon alhaisempi, kun hinnasta vähennettiin kaupasta ostettujen tuotteiden arvonlisävero. Käräjäoikeuden mukaan arvonlisäverotonta hintaa ei voitu kuitenkaan käyttää arvioitaessa hänen tietoisuutta laitteiden alkuperästä, koska vastaaja $Y$ oli ollut tietoinen siitä mahdollisuudesta, että olisi pystynyt itsekin hankkimaan vastaavia laitteita laillisesti arvonlisäveroa maksamatta. Tämä näkökohta sekä se, että hänen laitteista esirikoksen tekijälle maksama hinta toisen vastaajan läsnä ollessa oli ollut noin puolet niiden käyvistä hinnoista, osoitti edellä mainittujen seikkojen lisäksi vastaajien olleen tietoisia laitteiden laittomasta alkuperästä. ${ }^{\mathbf{7 7}}$ Anastusrikosten ollessa esirikoksina voidaan kiinnittää huomiota myös anastetun kaltaisen omaisuuden yleisyyteen kuluttajien keskuudessa. Näin oli esimerkiksi tapauksessa, jossa syytetty oli pitänyt hallussaan anastusrikoksilla saatuja valvontakameroita sekä videokameraa, jonka hän oli saanut haltuunsa ystävältään. Valvontakameroiden osalta syytetty oli tunnustanut aavistaneensa niiden olevan anastusrikoksella saatuja. Sen sijaan syytetyn tietoisuutta videokameran laittomasta alkuperästä osoitti se, että se oli arvokas alan koulutuksessa käytettävä kamera, joka oli kokonsakin puolesta selvästi erilainen kuin kuluttajien käytössä tavallisesti olevat kamerat. Sen vuoksi käräjäoikeus katsoikin, että syytetyn oli täytynyt mieltää kamera rikoksella hankituksi saadessaan sen ystävältään. ${ }^{\mathbf{7 8}}$

Ratkaisuja tarkastelemalla voidaan havaita, että tekijän tietoisuutta varojen laittomasta alkuperästä voivat osoittaa erilaiset objektiivisesti havaittavat tekijän toimet sekä ulkoiset olosuhteet.Usein ratkaisuissa on kiinnitetty huomiota esimerkiksitoiminnan poikkeuksellisuuteen, jolle ei sinänsä ole laillisessa menettelyssä perusteltua syytä. Toisaalta jonkinlaisena lähtökohtana voidaan myös pitää sitä, että mitä läheisempiä rahanpesijä ja esirikoksen tekijä ovat, sitä helpommin rahanpesijän on katsottu voivan mieltää varat rikoksella saaduiksi. ${ }^{79}$ Tekijän tietoisuutta varojen laittomasta alkuperästä voivat osoittaa myös hänellä tiedossa olleet seikat, jotka koskevat usein muun muassa esirikoksen tekijän taloudellisia vaikeuksia sekä aikaisempaa rikollisuutta. Toisaalta kyse voi olla yhtä hyvin sellaisista tekijän tiedossa olleista seikoista,

77 Pohjanmaan käräjäoikeus 8.7.2014 nro 129014

78 Oulun käräjäoikeus 6.2.2017 nro 104989.

79 Näin myös Sahavirta 2007, s. 162. 
jotka on mahdollista omaksua jo yleisen elämänkokemuksen perusteella. Tätä kuvastaa hyvin esimerkiksi edellä selostettu ratkaisu, jossa tekijän katsottiin jo yleisen elämänkokemuksen vuoksi täytyneen tietää, että elinkeinotoiminnasta saaduista tuloista täytyy suorittaa veroa. Kysymys on siis hyvin perustavanlaatuisesta tietämyksestä, joka jokaisen tulisi hallita.

\section{JOHTOPÄÄTÖKSET}

Kirjoituksessa tarkastelin rahanpesijän tietoisuutta varojen laittomasta alkuperästä tahallisuusvaatimuksena. Tavoitteenani oli selvittää, mitä kyseisen tahallisuusvaatimuksen täyttyminen edellyttää. Olen arvioinut tekijän tietoisuutta varojen laittomasta alkuperästä yhtäältä teoreettisesta näkökulmasta ja toisaalta aikaisemman rahanpesua koskevan oikeuskäytännön kautta pyrkiessäni konkretisoimaan tahallisuusarviointiin vaikuttavia seikkoja.

Päädyn siihen, että rahanpesijän tietoisuudessa varojen laittomasta alkuperästä on kyse tekijän tietoisuudelle asetetusta tahallisuusvaatimuksesta. Tekijän tahallisuuden kohteena on varojen laiton alkuperä, johon tahallisuuden täytyy tekohetkellä peittämisperiaatteen mukaisesti ulottua. Tekijältä ei edellytetä yksityiskohtaisia tietoja varojen alkuperästä, vaan teko voidaan syyksilukea tahallisena silloin, kun tekijä on ylipäätään mieltänyt omaisuuden olevan varsin todennäköisesti jollakin rikoksella hankittua. Jos tekijän mieltäminen varojen laittomasta alkuperästä ei ole yltänyt "varsin todennäköisenä pitämisen" tasolle, tahallisuus ei täyty, vaan kyseessä voi olla korkeintaan tuottamuksellinen rahanpesu. Nähdäkseni joissakin tilanteissa tekijän tahallisuus voi kuitenkin olla mahdollista perustaa selonottovelvollisuuden laiminlyöntiin, vaikka tekijä ei olisi mieltänyt varoja rikoksella saaduiksi yli 50 prosentin todennäköisyydellä. Selonottovelvollisuus mahdollistaa tahallisena rankaisemisen joustavasti etenkin sellaisissa tilanteissa, joissa tekijä ei ole rikosvastuun välttämiseksi halunnut ottaa selvää hänen kannaltaan epäedullisista seikoista lainkaan tai mikäli tekijä ei ole riittävästi pyrkinyt varmistumaan varojen alkuperästä. Näkemykseni on, että tekijällä on velvollisuus pyrkiä selvittämään omaisuuden alkuperä aina, kun hän voi yleisen elämänkokemuksen perusteella havaita teko-olosuhteiden olevan epäilyttävät. Perustettaessa tahallisuus selonottovelvollisuuden laiminlyöntiin olosuhdetahallisuudella ei ole tosiasiallista alarajaa, vaan ratkaisun syyksilukeminen perustuu tekijän täysin passiiviseen menettelyyn tai riittämättömiin selvittämistoimenpiteisiin

Tahallisuusvaatimus ei välttämättä täyty kaikissa tilanteissa. Tekijän tahallisuuden voi nimittäin erehdystilanteissa poistaa rikoslain 4 luvun $1 \S$ :n tunnusmerkistöerehdyssäännös, mikäli tekijä ei ole ollut selvillä varojen laittomasta alkuperästä tai hän on erehtynyt siitä, ovatko varat rikoksella hankittuja. On kuitenkin huomattava, että tekijän tarkoituksellinen tietämättömyys varojen laittomasta alkuperästä ei voi tulla kysymykseen rikoslain 4 luvun $1 \S: n$ tunnusmerkistöerehdyksenä. Kysymys on tällöin tekijän tietoisesta päätöksestä pysyä tietämättömänä rahanpesutunnusmerkistön täyttävistä olosuhteista, minkä voidaan katsoa osoittavan tekijän tahallisuutta.
Käytännössä tahallisuutta suhteessa varojen laittomaan alkuperään arvioidaan siten, onko tekijä voinut pitää varoja rikoksella saatuina hänellä tiedossa olleiden sekä muiden objektiivisesti havaittavien seikkojen perusteella. Nähdäkseni tahallisuusvaatimuksen täyttymistä arvioitaessa voidaan kiinnittää huomiota osin erilaisiin seikkoihin, kun kyse on eri esirikoksista. Esimerkiksi ratkaisussa, joissa rahanpesun esirikoksena oli törkeä huumausainerikos, tahallisuuden täyttymistä perusteltiin muiden seikkojen ohella sillä, että tekijä oli tiennyt esirikoksen tekijän huumausainerikostuomiosta. Tähän rinnastettavana tietona voitaisiin toisaalta pitää myös esirikoksen tekijän vankilassaoloa, jonka perusteella rahanpesijä voi varmemmin mieltää varat rikoksella saaduiksi. Sinänsä näiden seikkojen avulla tekijän tietoisuutta varojen laittomasta alkuperästä voidaan osoittaa muidenkin rahanpesun esirikosten kohdalla. Sen sijaan tekijän tietoisuudella veropetoksella saaduista varoista merkitystä oli yleiseen elämänkokemukseen perustuvalla tiedolla siitä, että elinkeinotoiminnasta saaduista tuloista on maksettava veroa, ja tekijän havainnolla, että tällainen velvollisuus oli laiminlyöty. Elinkeinotoimintaan liittyvien rikosten kohdalla on voitu ottaa huomioon toisaalta sekin, että varoihin liittyvilläjärjestelyillä ei ole ollut mitään järkevää perustetta kyseisessä toiminnassa. Anastusrikosten ollessa esirikoksina huomioon on voitu ottaa esimerkiksi anastettua omaisuutta vastaavan omaisuuden yleisyys kuluttajien keskuudessa. Tekijän tietoisuutta omaisuuden rikoksella hankitusta luonteesta voikin tekemieni havaintojen perusteella osoittaa tällöin esimerkiksi se, että kyse on tavallista arvokkaammasta tai harvinaisemmasta omaisuudesta, jota esirikoksen tekijä ei ole voinut saada haltuunsa muuten kuin rikoksella.

Rahanpesussa tekijän tietoisuus varojen laittomasta alkuperästä merkitsee siis tahallisuutta olosuhdetahallisuusarvioinnin kannalta. Tahallisuusvaatimus täyttyy tekijän mieltäessä varojen laittoman alkuperän todennäköisemmäksi vaihtoehdoksi kuin sen, että varat eivät ole rikoksella saatuja. Käytännössä tahallisuus päätellään teon olosuhteista, jolloin huomiota kiinnitetään tapauksesta riippuen eri seikkoihin. 


\section{LÄHTEET}

\section{Kirjalliset lähteet}

Frände, Dan: Yleinen rikosoikeus. Suomentanut Markus Wahlberg. Helsinki, Edita 2005. (Frände 2005)

Frände, Dan: Yleinen rikosoikeus. Suomentanut ja seuraamusosan päivittänyt Markus Wahlberg. 2. uudistettu painos. Helsinki, Edita 2012. (Frände 2012)

Heikinheimo, Sanna: Rahanpesu, erityisesti kriminalisoinnin ja konfiskaation näkökulmasta. Helsinki, Helsingin yliopisto 1998. (Heikinheimo 1998)

Hyttinen, Tatu: Olosuhdetahallisuuden vakioitu alaraja - Oikeusturvaa vai korkeimman oikeuden retoriikkaa. Defensor Legis N:o 6/2016 s. 916-933. (Hyttinen 2016)

Hyttinen, Tatu: Rahanpesun esirikoksen toteennäyttämiskynnys. Defensor Legis N:o 6/2017 s. 833-851. (Hyttinen 2017)

Keskeiset rikokset: Dan Frände - Jussi Matikkala - Jussi Tapani - Matti Tolvanen - Pekka Viljanen - Markus Wahlberg. 3., uudistettu ja laajennettu laitos. Helsinki, Edita 2014. (Tapani 2014)

Koponen, Pekka: Tahallisuudesta talousrikoksissa. Oikeustiede - Jurisprudentia 35/2002 s. 237-342. (Koponen 2002)

Koponen, Pekka: Talousrikokset rikos- ja prosessioikeuden yhtymäkohdassa. Erityisesti tahallisuuden ja syytesidonnaisuuden kannalta tarkasteltuna. Suomalaisen Lakimiesyhdistyksen julkaisuja, A-sarja n:o 249. Helsinki, Suomalainen lakimiesyhdistys 2004. (Koponen 2004)

Koponen, Pekka: Ongelmallinen olosuhdetahallisuus meillä ja Yhdysvalloissa - ovatko systematiikka ja yhdenvertaisuus ylläpidettävissä? Defensor Legis N:o 1/2007 s. 37-53. (Koponen 2007)

Matikkala, Jussi: Tahallisuudesta rikosoikeudessa. Suomalaisen Lakimiesyhdistyksen julkaisuja, A-sarja n:o 263. Helsinki, Suomalainen Lakimiesyhdistys 2005. (Matikkala 2005)

Matikkala, Jussi: KKO 2006:64 - tahallisuus ja huumausaineen laatu. Lakimies 1/2007 s. 109-118. (Matikkala 2007)

Neira, Taina - Perämaa, Juha - Vasara, Pekka: Rahanpesurikokset oikeuskäytännössä II. Keskusrikospoliisi. Rahanpesun selvittelykeskus. 2/2003. (Neira - Perämaa - Vasara 2003)

Nuutila, Ari-Matti: Rikoslain yleinen osa. Helsinki, Lakimiesliiton kustannus 1997. (Nuutila 1997)
Sahavirta, Ritva: Rahanpesurikokset. Teoksessa: Lahti, Raimo - Koponen, Pekka (toim.): Talousrikokset. Helsinki, Suomalainen Lakimiesyhdistys 2007 s. 145-176. (Sahavirta 2007)

Sahavirta, Ritva: Rahanpesu rangaistavana tekona. Suomalaisen Lakimiesyhdistyksen julkaisuja, A-sarja n:o 286. Helsinki, Suomalainen Lakimiesyhdistys 2008. (Sahavirta 2008)

Tapani, Jussi: Olisiko nyt sanottu viimeinen sana olosuhdetahallisuuden alarajasta? KKO 2012:66 ja seksuaalipalveluiden ostamisen rangaistavuus. Defensor Legis N:o 5/2012 s. 607-619. (Tapani 2012)

Tapani, Jussi: Esirikoksen yksilöitävyys ja olosuhdetahallisuus. Defensor Legis N:o 5/2013 s. 786-798. (Tapani 2013)

Tapani, Jussi - Tolvanen, Matti: Rikosoikeuden yleinen osa - Vastuuoppi. Helsinki, Talentum 2008. (Tapani - Tolvanen 2008)

Tapani, Jussi - Tolvanen, Matti: Rikosoikeuden yleinen osa - Vastuuoppi. 2. uudistettu painos. Helsinki, Talentum 2013. (Tapani - Tolvanen 2013)

Vihriälä, Helena: Tahallisuuden näyttäminen. Helsinki, Forum iuris - Helsingin yliopiston oikeustieteellisen tiedekunnan julkaisut 2012. (Vihriälä 2012)

\section{Virallislähteet}

HE 66/1988 vp. Hallituksen esitys Eduskunnalle rikoslainsäädännön kokonaisuudistuksen ensimmäisen vaiheen käsittäväksi rikoslain ja eräiden muiden lakien muutoksiksi.

HE 180/1992 vp. Hallituksen esitys Eduskunnalle rikoslain täydentämisestä huumausainerikoksia koskevilla säännöksillä.

HE 53/2002 vp. Hallituksen esitys Eduskunnalle eräiden rikoslain talousrikossäännösten ja eräiden niihin liittyvien lakien muuttamiseksi.

HE 44/2002 vp. Hallituksen esitys eduskunnalle rikosoikeuden yleisiä oppeja koskevan lainsäädännön uudistamiseksi.

LaVM 28/2002 vp. Lakivaliokunnan mietintö n:o 28 koskien hallituksen esitystä rikosoikeuden yleisiä oppeja koskevan lainsäädännön uudistamiseksi (HE 44/2002 vp).

LaVM 31/2010 vp. Lakivaliokunnan mietintö hallituksen esityksestä laeiksi rikoslain 32 luvun 6 §:n ja 14 §:n sekä kansainvälisestä oikeusavusta rikosasioissa annetun lain 15 §:n muuttamisesta. 


\section{Oikeuskäytäntö \\ KKO 2006:64 \\ KKO 2009:59 \\ KKO 2012:66 \\ KKO 2013:17 \\ KKO 2013:55}

Turun hovioikeus 13.1.2017 nro 101426

Vaasan hovioikeus 11.1.2013 nro 21

Espoon käräjäoikeus 29.8.2014 nro 134991

Etelä-Pohjanmaan käräjäoikeus 29.1.2014 nro 104205

Helsingin käräjäoikeus 19.12.2014 nro 156229

Jyväskylän käräjäoikeus 4.12.2009 nro 2548

Kemi-Tornion käräjäoikeus 18.11.2016 nro 148566

Lapin käräjäoikeus 10.10.2014 nro 143076

Länsi-Uudenmaan käräjäoikeus 17.4.2015 nro 115766

Oulun käräjäoikeus 6.2.2017 nro 104989

Pirkanmaan käräjäoikeus 9.6.2017 nro 123861

Pirkanmaan käräjäoikeus 27.3.2015 nro 114281

Pohjanmaan käräjäoikeus 8.7.2014 nro 129014

Pohjois-Karjalan käräjäoikeus 28.9.2012 nro 1757 